\title{
PENGARUH PENAMBAHAN EKSTRAK TEH HIJAU (Camellia sinensis) DALAM BAHAN PENGENCER KUNING TELUR SITRAT TERHADAP KUALITAS SPERMATOZOA DOMBA SAPUDI YANG DISIMPAN PADA SUHU DINGIN
}

\section{THE EFFECT OF THE ADDITION OF GREEN TEA EXTRACT (Camellia sinensis) IN EGG YOLK CITRATE DILUENT FOR QUALITY SAPUDI SHEEP SPERMATOZOA STORAGE ON COLD TEMPERATURE}

\author{
Itrah Khoirunnisa $^{1)}$, ${ }^{*}$ Suherni Susilowati ${ }^{2)}$, Lilik Maslachah ${ }^{3)}$, Tri Wahyu \\ Suprayogi $^{4}$, Rochmah Kurnijasanti ${ }^{5)}$, Hermin Ratnani ${ }^{6)}$ \\ ${ }^{1)}$ Student, ${ }^{2,4,6)}$ Departement of Veterinary Reproduction, ${ }^{3,5}$ Departement of Veterinary Basic \\ Medical Science \\ Faculty of Veterinary Medicine, Universitas Airlangga \\ *Corresponding author: email: suhernifkhunair@gmail.com; ithrahkhoirunnisa16@gmail.com
}

\begin{abstract}
The purpose of this research was determine the effect and the best concentration of greentea extract in egg yolk citrate diluent for quality Sapudi sheep spermatozoa were measured in motility, viability and intact plasma membrane that was stored on cold temperature. The semen was devided into four groups : egg yolk citrate diluent, $0,05 \%$ green tea extract in egg yolk citrate diluent, $0,1 \%$ green tea extract in egg yolk citrate diluent and $0,15 \%$ green tea extract in egg yolk citrate diluent. Spermatozoa quality was observed day 1 , day 2, day 3 , day 4 and day 5 after diluent. The data obtained was analyzed with the analysis of variance (ANOVA), followed by multiple range test duncan. The result showed that the higest precentage of motility, viability and intact plasma membran were obtained from $0,05 \%$ green tea extract in egg yolk citrate diluent for 1 day of storage which were $85.83 \pm 3.76,91.16 \pm 2.13$ and $66.83 \pm 6.49$. The lowest precentage of motility, viability and intact plasma membrane were obtained from egg yolk citrate diluent for 5 day of storage which were $26.66 \pm 6.05,49.16 \pm 6.43$ and $26.66 \pm 4.32$. Conclution of this research was the addition of $0,05 \%$ green tea extract can be used as a diluent could maintain the precentage of spermatozoa quality until 5 days after diluent.
\end{abstract}

Keyword : egg yolk citrate, green tea extract, spermatozoa quality, sapudi sheep

\section{Pendahuluan}

Inseminasi Buatan (IB) adalah suatu kegiatan yang dilakukan inseminator agar hewan betina bunting dengan cara memasukkan semen ke dalam saluran reproduksi hewan betina yang sedang birahi (Herawati dkk., 2012). Program IB diharapkan dapat mengoptimalkan penggunaan semen, hal ini dikarenakan semen dari pejantan unggul dapat mengawini lebih banyak betina (Rahardian dkk., 2012).

Kegiatan IB di Indonesia pada ternak domba dilakukan pertama kali pada tahun 1991, di stasiun penelitian Sub Balai Penelitin Ternak, Sei Putih (Inounu, 2014). Domba Sapudi merupakan ternak pedaging yang memiliki ciri khas yaitu ekor panjang dan bagian pangkal ekor gemuk yang mam- pu menimbun banyak lemak. (Rosyidi, 2009).

Keberhasilan program IB ditentukan oleh beberapa faktor utama yaitu kualitas semen, kesuburan ternak betina, keterampilan teknisi dan pengetahuan zooteknik peternak (Rizal dan Herdis, 2010).

Keutuhan membran plasma sangat diperlukan oleh spermatozoa, karena kerusakan membran plasma akan berpengaruh terhadap proses metabolisme yang berhubungan dengan motilitas dan viabilitas spermatozoa (Pratiwi dkk., 2015).

Proses metabolisme secara normal akan menghasilkan radikal bebas. Reaksi radikal bebas ditandai dengan terbentuknya peroksidasi lipid yang menyebabkan terganggunya keutuhan membran plasma sperma- 
tozoa (Kewilaa dkk., 2014). Peroksidasi lipid yang berlangsung lama dapat merusak struktur matriks lipid dan menyebabkan membran sel tidak stabil, mengubah fungsi membran serta menurunkan fluiditas membran sperma (Sukmawati dkk., 2014).

Antioksidan merupakan senyawa yang digunakan untuk menghambat atau menekan kerusakan yang ditimbulkan oleh aktivitas radikal bebas (Rizal dan Herdis 2010). Penelitian Nugroho dkk. (2014) menyebutkan bahwa penambahan zat antioksidan pada pengencer dapat mencegah aktivitas radikal bebas terhadap kerusakan membran sel spermatozoa yang berpengaruh terhadap viabilitas dan fertilitas spermatozoa, berperan sebagai sumber energi untuk mempertahankan motilitas spermatozoa.

Teh Hijau yang dihasilkan dari pemrosesan daun teh (Camelia sinensis) mempunyai aktivitas antioksidan yang cukup kuat. Salah satu senyawa utama paling berpengaruh terhadap mutu daun teh hijau adalah katekin (Anjarsari, 2016). Kemampuan melawan radikal bebas oleh katekin berhubungan dengan struktur kimia dari tiap komponen katekin, gallate teresterifikasi pada posisi 3 cincin $C$, gugus catechol (gugus 3,4-dihydroxyl) pada cincin B, dan gugus hidroksil pada posisi 5 dan 7 cincin A. Katekin juga dapat melindungi sel dari proses pembentukan ROS, proses peroksidasi lipid dan deaminasi DNA yang diinduksi oleh Oxidative Stress (OS) (Sutherland et al., 2006 dalam Agung dkk.,2013).

Penyimpanan pada suhu dingin selain menyebabkan terjadinya kejutan dingin pada spermatozoa juga mengakibatkan $O k$ sidatif Stress (OS) atau terjadi serangan ROS, untuk itu dalam pengencer perlu ditambahkan antioksidan (Bebas dan Gorda, 2016). Oxidatif Stress (OS) pada spermatozoa akibat pendinginan akan merubah konfigurasi dari fosfolipid membran plasma dan mengganggu fungsi dan permeabilitas membran sel sehingga menyebabkan membran plasma rusak.

Kuning telur mengandung lipoprotein dan lesitin yang diperlukan dalam semen cair yang disimpan pada suhu $5{ }^{\circ} \mathrm{C}$ (Kewilaa dkk., 2014). Lipoprotein dan lesitin yang terdapat pada kuning telur dapat mempertahankan dan melindungi spermatozoa dari cekaman dingin
(Permatasari dkk., 2013). Kuning telur juga mengandung glukosa yang dapat digunakan sebagai sumber energi bagi spermatozoa (Suteky dkk., 2008).

Penelitian dengan penambahan antioksidan menggunakan ekstrak teh hijau telah dilakukan oleh Agung dkk. (2013) pada sapi menggunakan bahan pengencer Tris-Kuning Telur yang mendapatkan hasil terbaik dari kelompok perlakuan lainnya dengan penambahan ekstrak teh hijau dengan konsentrasi paling tinggi yaitu konsentrasi $0,15 \%$.

Berdasarkan uraian di atas, maka pada penelitian ini ingin mengetahui pengaruh penambahan ekstrak teh hijau (Camellia sinensis) dalam bahan pengencer kuning telur sitrat terhadap kualitas spermatozoa semen domba Sapudi yang diukur dalam motilitas, viabilitas dan keutuhan membran plasma spermatozoa yang disimpan pada suhu dingin sehingga dapat diketahui persentase optimal pemberian ekstrak teh hijau yang mampu mempertahankan kualitas spermatozoa domba selama penyimpanan.

\section{Materi Dan Metode \\ Sampel dan Besaran Sampel}

Sampel yang digunakan dalam penelitian ini adalah semen dari seekor domba Sapudi jantan. Penampungan semen dilakukan seminggu 2 kali selama 3 minggu untuk 6 kali pengulangan menggunakan 4 perlakuan.

\section{Cara Pembuatan Ekstrak Teh Hijau (Camellia sinensis)}

Daun teh hijau kering yang diperoleh dari perkebunan teh di Bandung, Jawa Barat diekstraksi dengan proses maserasi menggunakan pelarut etanol 96\%. Ekstrak kental teh hijau yang didapatkan kemudian di freeze driying untuk memperoleh ektrak kering.

\section{Pembuatan Kuning Telur Sitrat}

Larutan natrium sitrat dibuat dengan mencampurkan Na-sitrat $\left(\mathrm{Na}_{2} \mathrm{C}_{6} \mathrm{H}_{5} \mathrm{O}_{7}\right.$. $2 \mathrm{H}_{2} \mathrm{O}$ ) sebanyak 2,9 gram dengan $100 \mathrm{ml}$ aquades. Kerabang kuning telur kemudian dipecah pada bagian yang tumpul (rongga udara) untuk mengeluarkan putih telurnya. Kuning telur yang sudah terpisah dari putihnya kemudian ditambahkan larutan natrium sitrat dengan perbandingan antara 
kuning telur dan larutan natrium sitrat adalah 1:4 (untuk menjamin fertilitas yang optimum). Pengencer kuning telur sitrat lalu ditambah dengan penisilin 1000 IU dan streptomisin $1 \mathrm{mg} / \mathrm{ml}$ bahan pengencer dan dihomogenkan (Susilowati dkk., 2010).

\section{Pembagian Kelompok Perlakuan}

-Kontrol (P0) : semen domba $+20 \mathrm{ml}$ kuning telur sitrat

-Perlakuan 1(P1) : semen domba $+20 \mathrm{ml}$ kuning telur sitrat + ekstrak teh hijau 0,05\% $(0,01$ gram teh hijau $)$

-Perlakuan $2(\mathrm{P} 2)$ : semen domba $+20 \mathrm{ml}$ kuning telur sitrat + ekstrak teh hijau $0,1 \%$ $(0,02$ gram teh hijau)

-Perlakuan 3 (P3) : semen domba $+20 \mathrm{ml}$ kuning telur sitrat + ekstrak teh hijau $0,15 \%$ ( 0,03 gram teh hijau)

Pada masing-masing perlakuan dilakukan pengukuran derajat keasaman $(\mathrm{pH})$ sebelum dimasukkan ke dalam tabung reaksi dan kemudian ditutup rapat. Tabung reaksi selanjutnya dimasukkan ke dalam beker glass yang berisi air bersih lalu dipreservasi di dalam lemari es (refrigenerator) yang bersuhu $5^{\circ} \mathrm{C}$. Masing-masing perlakuan dievaluasi kualitasnya setiap hari selama 5 hari atau hingga persentase motilitas spermatozoa progresif $\leq 40 \%$. Pemeriksaan dilakukan untuk mengetahui persentase dari motilitas, viabilitas dan keutuhan membran plasma spermatozoa.

\section{Tempat dan Waktu Penelitian}

Penelitian dilaksanakan di Laboratorium Inseminasi Buatan Fakultas Kedokteran Hewan Universitas Airlangga untuk pembuatan bahan pengencer yang dibutuhkan untuk perlakuan pada semen domba. Penampungan semen domba dilakukan di kandang peternakan Fakultas Kedokteran Hewan Universitas Airlangga. Proses ekstraksi teh hijau dilakukan di Eks. Laboratorium Farmakologi Departemen Kedokteran Dasar Fakultas Kedokteran Hewan Universitas Airlangga, Surabaya. Penelitian ini dilaksanakan pada bulan Mei - Juni 2018.

\section{Bahan dan Alat Penelitian}

Bahan yang digunakan dalam penelitian ini adalah : semen domba Sapudi, kuning telur ayam, natrium sitrat, teh hijau kering, etanol 96\%, air hangat, vaseline, aquades, 1 vial Penisilin, 1 vial Streptomisin, larutan $\mathrm{NaCl}$ fisiologis, alkohol 70 $\%$, spirtus, pewarna Eosin-Negrosin dan larutan HOS.

Peralatan yang digunakan dalam penelitian ini adalah : vagina buatan 1 set, tabung berskala, tabung reaksi, rak tabung, timbangan digital analitik, erlenmeyer, kertas saring, kertas label, spuit $1 \mathrm{ml}$, batang pengaduk, pembakar bunsen, termos air, mikroskop cahaya, gelas objek, gelas penutup, termometer, rotary evaporator, freeze dryer, spektrofotometer, beker glass, gelas ukur, kertas $\mathrm{pH}$, pipet tetes, pipet hisap, aluminium foil, tissue, dan lemari pendingin.

\section{Pengolahan Data}

Data yang diperoleh berupa rata-rata dan simpangan baku yang disusun dalam satu tabel. Data dianalisis dengan menggunakan Analysis of Variant (ANOVA) untuk mengetahui perbedaan motilitas, viabilitas dan keutuhan membran plasma pada kelompok perlakuan. Data kemudian dianalisis lebih lanjut dengan Uji jarak Berganda Duncan's dengan tingkat signifikan 5\% apabila terdapat perbedaan untuk mengetahui kelompok mana yang terbaik (Kusriningrum, 2010).

\section{Hasil Dan Pembahasan Penelitian Motilitas Setelah Pengenceran}

Hasil pada penelitian ini menunjukkan rata-rata persentase motilitas spermatozoa domba Sapudi dari persentase tertinggi hingga persentase terendah yang disimpan pada suhu dingin pada hari ke-5 adalah P1 sebesar 40\%, P2 sebesar 35,83\%, P3 sebesar 32,5\%, dan P0 sebesar 26,66\%. Pada kelompok pengencer dengan penambahan ekstrak teh hijau dapat lebih mempertahankan motilitas spermatozoa dari kerusakan yang ditimbulkan oleh serangan radikal bebas yang memicu ROS dan peroksidasi lipid. Rizal dkk. (2003) menyebutkan bahwa kerusakan pada membran plasma dapat menyebabkan hilangnya enzim-enzim yang diperlukan dalam proses metabolisme sehingga tidak dihasilkan energi yang menyebabkan motilitas menjadi rendah serta daya hidup juga rendah. 


\section{Viabilitas Setelah Pengenceran}

Hasil pada penelitian ini menunjukkan rata-rata persentase viabilitas spermatozoa domba Sapudi dari nilai tertinggi hingga nilai terendah yang disimpan pada suhu dingin pada hari ke-5 adalah P1 sebesar $59,83 \%$, P2 sebesar 57,33\%, P3 sebesar $55,5 \%$, dan P0 sebesar $49,16 \%$. Semakin tinggi penambahan ekstrak teh hijau, persentase viabilitas spermatozoa domba Sapudi semakin menurun. Dosis antioksidan yang terlalu tinggi akan menyebabkan toksik terhadap sel spermatozoa. Sifat toksik disebabkan oleh pemberian antioksidan yang berlebihan sehingga menyebabkan meningkatnya tekanan osmosis dan menyebabkan kerusakan membran spermatozoa yang berdampak pada putusnya ekor spermatozoa (Wilandari dkk, 2013).

\section{Keutuhan Membran Plasma Setelah Pengenceran}

Hasil pada penelitian ini menunjukkan rata-rata persentase membran plasma utuh spermatozoa domba Sapudi dari nilai tertinggi hingga nilai terendah yang disimpan pada suhu dingin pada hari ke-5 adalah P1 sebesar 36,16\%, P2 sebesar 32\%, P3 sebesar 30,33\%, dan P0 sebesar 26,66\%. Hasil penelitian pada persentase membran plasma yang utuh ini mendapatkan urutan yang sama dengan pemeriksaan motilitas dan viabilitas setelah perlakuan. Hal tersebut sesuai dengan pendapat Ariantie dkk. (2013) yang menyebutkan terdapat hubungan antara membran plasma utuh dengan motilitas dan viabilitas spermatozoa.

\section{Kesimpulan}

Penambahan ekstrak teh hijau ( $\mathrm{Ca}$ mellia sinensis) dengan konsentrasi $0,05 \%$ dalam bahan pengencer kuning telur sitrat dapat mempertahankan motilitas, viabilitas dan keutuhan membran plasma spermatozoa domba Sapudi yang di simpan pada suhu dingin.

\section{Daftar Pustaka}

Agung, B., W. Handang dan M.M.P. Sirat. 2013. Peningkatan Kualitas Post Thawing Spermatozoa Epididimis Sapi dengan Suplementasi Catechin sebagai Antioksidan pada Pengencer Semen. Jurnal Ilmu Ternak. 13 (2) : 34-36.
Anjarsari, I.R.D. 2016. Katekin Teh Indonesia : Prospek dan Manfaatnya. Jurnal Kultivasi. 15(2): 99-106.

Ariantie, O.S., T.L. Yusuf, D. Sajuthi dan R.I. Arifiantini. 2013. Pengaruh Krioprotektan Gliserol dan Dimethilformamida dalam Pembekuan Semen Kambing Peranakan Etawah Menggunakan Pengencer Tris Modifikasi . Jurnal Ilmu Ternak Veteriner. 18(4): 239-250.

Bebas, W. dan W. Gorda. 2016. Penambahan Astaxanthin pada Pengencer Kuning Telur Berbagai Jenis Unggas Dapat Memproteksi Semen Babi selama Penyimpanan. Jurnal Veteriner. 17(4): 484-491.

Harianto, B. 2012. Petunjuk Praktis Penggemukan Domba. Agromedia. Jakarta.

Herawati, T., A. Anggraeni, L. Praharani, D. Utami dan A. Argiris. 2012. Peran Inseminator dalam Keberhasilan Inseminasi Buatan pada Sapi Perah Inseminator Role in The Success of Artificial Insemination on Dairy Cattle. Jurnal Informatika Pertanian. 21(2): 81 -88 .

Inounu, I. 2014. Upaya Meningkatkan Keberhasilan Inseminasi Buatan pada Ternak Ruminansia Kecil. Jurnal Wartazoa. 24(4): 201-209.

Kewilaa, A.I., Y.S. Ondho dan E.T. Setiatin. 2014. Efisiensi Penambahan Kuning Telur dalam Pembuatan Pengencer Air Kelapa-Kuning Telur terhadap Kulaitas Spermatozoa pada Semen Cair Domba Ekor Tipis (DET). Jurnal Agribis-nis Kepulauan. 2(2): 112.

Kusriningrum. 2010. Perancangan Percobaan. Universitas Airlangga. Airlangga University Press. Surabaya.

Nugroho, Y., T. Susilawati dan S. Wahjuningsih. 2014. Kualitas Semen Sapi Limousin selama Pendinginan Menggunakan Pengencer Cep-2 dengan Penambahan Berbagai Konsentrasi Kuning Telur dan Sari Buah Jambu Biji (Psidium guajava). Jurnal Ternak Tropika. 15(1): $31-42$.

Permatasari, W.D., Setiatin, E.T dan Samsudewa, D. 2013. Studi tentang Pengencer Kuning Telur dan Pengaruhnya terhadap Kualitas Semen 
Beku Sapi Jawa Brebes. Animal Agriculture Journal. 2(1): 143-151.

Rizal, M.R., Toeliher, T.L. Yusuf, B. Purwantara dan P. Situmorang. 2003. Kriopreservasi Semen Domba Garut dalam Pengencer Tris dengan Konsentrasi Laktosa yang Berbeda. Jurnal Media Kedokteran Hewan. 19(2): 7983.

Rizal, M. dan Herdis. 2010. Peranan Antioksidan dalam Meningkatkan Kualitas Semen Beku. Jurnal Wartazoa. 20 (3) : 139-145.

Rosyidi, D. 2009. Kualitas Daging Domba Ekor Gemuk (DEG) Betina Periode Lepas Sapih dengan Perlakuan Docking dan Tingkat Pemberian Konsentrat Ditinjau dari Kadar Air, Lemak dan Protein. Jurnal Ilmu dan Teknologi Hasil Ternak. 4(2): 30-35.

Sukmawati, E., R.I. Arifiantini dan B. Purwantara. 2014. Daya Tahan Spermatozoa terhadap Proses Pembekuan pada Berbagai Jenis Sapi Pejantan Unggul. JITV. 19(3): 168-175.
Susilowati, S., Hardijanto, T. Hernawati, T. Sardjito dan TW. Suprayogi. 2010. Penuntun Praktikum Inseminasi Buatan. Fakultas Kedokteran Hewan. Universitas Airlangga. Airlangga University Press. Surabaya.

Suteky, T., Kadarsih, S. dan Novitasari, Y.Y. 2008. Pengaruh Pengencer Susu Skim dengan Sitrat Kuning Telur dan Lama Penyimpanan terhadap Kualitas Semen Kambing Persilangan Nubian dengan Peranakan Ettawa. Jurnal Sain Peternakan Indonesia. 3(2): 81-88.

Wilandari, T.D., A. Abdul dan M.Ibrahim. 2013. Pengaruh Pemberian Ekstrak Sarang Semut (Myrmecodia pedens Merr \& Perry) terhadap Morfologi Spermatozoa Tikus Putih (Rattus norvegicus L) yang Dipapar Asap Rokok. Universitas Negeri Gorontalo.

Yulnawati dan M.A. Setiadi. 2005. Motilitas dan Keutuhan Membran Plasma Spermatozoa Epididimis Kucing selama Penyimpanan pada Suhu $4^{\circ} \mathrm{C}$. Jurnal Media Kedokteran Hewan. 21(3): 100-104. 